\title{
Pengaruh Intellectual Capital Terhadap Kinerja Keuangan dan Nilai Perusahaan (Studi Kasus Perusahaan Sektor Keuangan yang Terdaftar di Bursa Efek Indonesia Tahun 2017-2019)
}

\author{
Ikhram Hafiz Rahmadi \\ IPB University \\ Ali Mutasowifin \\ IPB University \\ *Ikhram_hr@apps.ipb.ac.id \\ *alimu@apps.ipb.ac.id
}

\begin{abstract}
Abstrak
Berlainan dengan asset tradisional yang berwujud, intellectual capital merupakan hidden value yang kurang memperoleh perhatian. Penelitian ini menguji pengaruh intellectual capital terhadap kinerja keuangan dan nilai perusahaan. Penelitian ini menggunakan metode value added intellectual coefficient (VAIC) sebagai indikator untuk menghitung nilai intellectual capital perusahaan. Kinerja keuangan diukur oleh empat indikator yaitu Return on Assets (ROA), Return on Equity (ROE), Debt to Assets (DAR) dan Debt to Equity (DER). Nilai Perusahaan diukur oleh indikator Earning per Share (EPS), Price to Earning Ratio (PER), Price to Book Value Ratio (PBV), dan Tobin's Q. Penelitian ini menggunakan alat analisis Partial Least Square (PLS) dengan memanfaatkan aplikasi SmartPLS versi 3.2.2. Sampel dalam penelitian ini adalah perusahaan sektor keuangan pada Bursa Efek Indonesia pada 20172019. Hasil penelitian menunjukan bahwa terdapat pengaruh positif dan signifikan antara Intellectual Capital terhadap Kinerja Keuangan dan Nilai perusahaan.
\end{abstract}

Kata Kunci: Kinerja Keuangan, Nilai Perusahaan, Resource Based Theory, Value Added Intellectual Coefficient

\section{Pendahuluan}

Pada Era Industri 4.0, Persaingan bisnis di berbagai sektor semakin ketat. Dilansir dari Detik Finance, setidaknya ada sekitar 3,98 Juta Perusahaan baru di Indonesia dalam kurun waktu 10 tahun terakhir (Detik 2017). Persaingan yang sangat ketat juga terasa pada sektor keuangan. Setidaknya ada 103 bank yang bangkrut sejak 2006 hingga 2020 (Okezone 2020). Ada beberapa banyak faktor yang menyebabkan bank-bank tersebut tidak dapat survive dalam persaingan, salah satunya adalah ancaman financial technology (fintech). Pada tahun 2017 penyaluran pembiayaan dari fintech mencapai angka $800 \%$. Kekhawatiran akan invasi fintech dikonfirmasi oleh penelitian Pricewaterhouse Coopers (PwC) Indonesia yang menyatakan bahwa $83 \%$ dari Institusi keuangan tradisional khawatir bisnisnya direbut oleh fintech. Presiden Direktur PT Bank Central Asia, Jahja Setiaatmadja menuturkan bahwa bank tradisional harus bertransformasi ke digital jika tidak ingin ditinggalkan nasabah (CNBC 2020).

Dikarenakan persaingan yang semakin ketat, perusahaan harus menjalankan berbagai strategi agar perusahaan dapat tetap survive dan mendapatkan keuntungan yang maksimal. 
Salah satu cara agar perusahaan tetap bertahan di tengah persaingan yang ketat adalah mengoptimalkan penggunaan sumber daya yang dimiliki perusahaan. Sumber daya yang dimaksud adalah aset berwujud dan tidak berwujud. Perusahaan-perusahaan pada umumnya sudah mampu mengelola aset berwujudnya dengan baik namun belum semua menyadari pentingnya mengelola aset tidak berwujud. Ditambah pada era industri modern fokus pengembangan bisnis tidak lagi berfokus pada mesin-mesin melainkan beralih pada kemampuan sumber daya manusia yang terus melakukan inovasi. Hal ini menandakan bahwa mengelola sumber daya tak berwujud menjadi sangat penting bagi perusahaan untuk bertahan dan mendapatkan keuntungan.

Intellectual Capital (IC) merupakan hidden value yang dimiliki perusahaan. Hal tersebut dikarenakan Intellectual Capital tidak terlihat secara eksplisit seperti aset tradisional (aset berwujud) namun IC terlihat pada laporan keuangan yang diterbitkan (Edvinsson 1997). Perkembangan Ekonomi sangat dipengaruhi informasi dan pengetahuan karena kemajuan di bidang informasi dan teknologi yang membuat perhatian terhadap modal intelektual pun meningkat (Hong 2007). Menurut Ulum (2009) Intagible Asset Creation harus mendapatkan perhatian yang cukup dari perusahaan karena memiliki dampak yang baik bagi perusahaan. Lebih lanjut Ulum menjelaskan bahwa dalam konsep Value Creation, format berwujud seperti pendapatan, bergantung pada format tidak berwujud, misalnya jika perusahaan ingin menghasilkan laba yang maksimal maka diperlukan kinerja pelayanan maksimal agar menciptakan pelanggan yang setia (Customer Capital).

Nilai tambah dan keunggulan bersaing sangat diperhatikan oleh seluruh stakeholder perusahaan termasuk oleh investor. Investor akan menginvestasikan dananya kepada perusahaan-perusahaan yang dianggap memiliki nilai yang baik. Maka dari itu pengelolaan sumber daya perusahaan dengan baik dan efektif akan mampu meningkatkan nilai perusahaan. Perusahaan yang mampu mengelola sumber dayanya dan meningkatkan nilai perusahaan akan diminati oleh investor. Intellectual Capital merupakan salah satu umber daya yang perlu perusahaan kelola dengan baik. Menurut Chen et al., (2005) investor akan memberikan nilai lebih tinggi pada perusahaan yang memiliki efisiensi modal intelektual yang tinggi. Hal ini mengindikasikan bahwa modal intelektual mampu mempengaruhi persepsi pasar terhadap suatu perusahaan.

Terdapat banyak cara untuk mencari nilai Intellectual Capital namun sulit dilakukan karena data yang diperlukan untuk mengetahui nilai IC perusahaan merupakan data internal perusahaan. Adanya kesulitan di dalam pengukuran Intellectual capital secara langsung menyebabkan keberadaannya di dalam suatu perusahaan sulit untuk diketahui dan dilaporkan. Penggunaan metode Value Added Intellectual Coefficient (VAIC) yang di gagas oleh Ante Pulic (1998), dapat membantu dengan menghitung nilai intellectual dari sudut pandang moneter perusahaan berbasiskan data laporan keuangan. Perhitungan IC menggunakan VAIC memiliki kelebihan karena dapat dihitung oleh investor memanfaatkan data laporan keuangan perusahaan.

Berdasarkan pemaparan tersebut, penelitian ini bertujuan mengukur pengaruh intellectual capital yang diproyeksikan oleh nilai VAIC terhadap variabel-variabel yang sangat diperhatikan oleh investor ketika menilai suatu perusahaan yaitu kinerja keuangan dan nilai perusahaan. Kinerja keuangan perusahaan diukur menggunakan rasio Return on Equity (ROE), Return to Assets (ROA), Debt to Equity (DER), Debt to Assets (DAR) dan nilai perusahaan yang dilihat dari nilai Earning per Share (EPS), Price to Book Value (PBV), Price to Earning Ratio (PER) dan Tobin Ratio ( Tobin's Q). Penelitian ini memilih industri keuangan sebagai 
sampel penelitian. Hal ini dikarenakan industri keuangan merupakan Knowledge Intensive Services Activities (Lee et al., 2002). Windrum dan Tomlinson (1999) juga mengatakan bahwa industri keuangan merupakan industri yang intensif menggunakan ilmu pengetahuan, sebagaimana yang terlihat pada industri-industri di Belanda, UK, Jerman dan Jepang. Selain itu, berdasarkan penelitian Firer dan William (2006) industri perbankan merupakan industri yang paling intensif nilai intellectual capitalnya. Sehingga penelitian ini memiliki 2 rumusan masalah yaitu :

1. Bagaimana pengaruh intellectual capital terhadap kinerja keuangan perusahaan sektor keuangan yang terdaftar di Bursa Efek Indonesia

2. Bagaimana pengaruh intellectual capital terhadap nilai perusahaan sektor keuangan yang terdaftar di Bursa Efek Indonesia

3. Bagaimana pengaruh kinerja keuangan terhadap nilai perusahaan sektor keuangan yang terdaftar di Bursa Efek Indonesia

\section{Landasan Teori dan Pengembangan Hipotesis}

\section{Resource Based Theory}

Dalam pandangan resource based theory perusahaan akan unggul dalam persaingan usaha dan memiliki kinerja keuangan yang baik dengan cara memiliki, menguasai dan memanfaatkan aset-aset strategis yang penting (berwujud maupun tidak berwujud). Menurut Susanto (2007), ada dua hal utama yang dibutuhkan organisasi untuk dapat bersaing. Pertama, memiliki keunggulan dalam sumber daya baik aset berwujud maupun tidak berwujud. Kedua, kemampuan untuk mengelola sumber daya agar mampu dimanfaatkan secara efektif. Kombinasi dari aset dan kemampuan untuk memanfaatkannya diklaim akan menciptakan ciri khas tertentu bagi kompetensi perusahaan, sehingga lebih unggul dibandingkan dengan kompetitor. Intellectual Capital merupakan aset tak berwujud yang dimiliki perusahaan. Sesuai dengan pandangan resource based theory, kepemilikan dan pemanfaatan intellectual capital akan memberikan kompetensi kepada perusahaan untuk unggul dalam persaingan usaha.

\section{Teori Keagenan}

Berdasarkan teori stakeholder, penciptaan nilai tambah atau value creation merupakan tujuan akhir perusahaan. Stakeholder lebih menghargai perusahaan yang mampu menciptakan nilai karena dengan penciptaan nilai akan memberikan keuntungan bagi stakeholder. Berdasarkan penelitian Hendra Wijaya (2016) didapatkan kesimpulan bahwa Intellectual Capital mampu mereduksi konflik keagenan. Kesimpulan tersebut didasari bahwa efek negatif dari keputusan investasi, keputusan pendanaan dan kebijakan dividen dapat direduksi dengan adanya Intellectual Capital. Selain itu penelitian Chen et al (2005) juga menunjukkan bahwa Intellectual Capital memiliki pengaruh signifikan terhadap nilai perusahaan. Berdasarkan teori keagenan bahwa pemegang saham selaku principal lebih menghargai perusahaan yang mampu menciptakan nilai maka Intellectual Capital dalam hal ini sebagai pencipta nilai dipercaya dapat mengurangi konflik keagenan.

\section{Intellectual Capital}

Dalam penelitian Bontis et al. (2000) disebutkan bahwa secara umum, para peneliti mengidentifikasi Intellectual Capital dibentuk oleh tiga unsur utama yaitu: human capital (HC), structural capital (SC), dan customer capital (CC). HC merepresentasikan individual knowledge stock suatu organisasi yang direpresentasikan oleh karyawannya. HC disusun oleh unsur-unsur attitude, education, experience dan genetic inheritance tentang kehidupan dan 
bisnis. Sedangkan SC berarti membicarakan nonhuman storehouses of knowledge dalam organisasi. Database, organisational charts, process manuals, strategies, routines dan segala hal yang membuat nilai perusahaan lebih besar daripada nilai materialnya adalah unsur- unsur yang sangat berkaitan dengan SC, yakni pengetahuan perusahaan yang berkaitan dengan konsumennya seperti marketing channels dan customer relationship di mana organisasi mengembangkannya melalui jalannya bisnis (Bontis et al. 2000).

\section{Value Added Intellectual Coefficient (VAIC)}

Pulic (1998) menciptakan metode mengenai Intellectual Capital yang disebut VAIC ${ }^{\mathrm{TM}}$. Metode tersebut mampu mengukur value creation efficiency dari aset berwujud dan aset tidak berwujud yang dimiliki oleh perusahaan. VA (Value Added) merupakan komponen yang mendasari model pulic ini. Value Added menunjukan kemampuan perusahaan dalam menciptakan nilai (Value Creation) sehingga dianggap menjadi indikator paling objektif untuk menilai keberhasilan bisnis perusahaan. VA dipengaruhi oleh efisiensi dari Human Capital (HC) dan Structural Capital (SC). Metode VAIC memiliki keunggulan karena dapat menghitung nilai intellectual capital perusahaan dari laporan keuangan perusahaan. Hal ini penting bagi stakeholder eksternal perusahaan seperti investor ataupun peneliti karena laporan keuangan perusahaan publik bisa didapatkan dengan mudah.

\section{Kinerja Keuangan}

Menurut Fahmi (2012), kinerja keuangan adalah analisis untuk mengetahui seberapa jauh perusahaan telah melaksanakan kewajibannya dengan mengacu kepada aturan-aturan pelaksanaan keuangan secara baik dan benar. Sedangkan Sucipto (2003) mendefinisikan kinerja keuangan sebagai penentuan ukuran-ukuran tertentu yang dapat dijadikan ukuran keberhasilan perusahaan dalam menghasilkan laba. Kinerja keuangan pada penelitian ini diukur melalui rasio profitabilitas dan rasio solvabilitas.

Rasio profitabilitas digunakan untuk mengetahui dan menilai kemampuan perusahaan mencetak laba (Kasmir 2010). Rasio profitabilitas dapat digunakan untuk menarik minat investor yang akan menilai lebih perusahaan dengan kinerja baik terutama dalam kemampuan mencetak laba. Rasio profitabilitas yang digunakan dalam penelitian ini adalah Return on Assets (ROA) dan Return on Equity (ROE). ROA menunjukan kemampuan perusahaan mengelola aset yang dimilikinya dengan seefektif mungkin untuk menciptakan laba setinggi mungkin. Sedangkan ROE mengukur kemampuan perusahaan menciptakan laba bagi pemegang saham.

Selain rasio profitabilitas, penelitian ini menggunakan rasio solvabilitas dalam mengukur kinerja keuangan. Rasio ini menggambarkan kemampuan perusahaan membayar kewajiban jangka panjangnya. Rasio solvabilitas mengukur seberapa banyak kontribusi utang dalam operasi perusahaan, sehingga stakeholder mampu mengukur kesehatan keuangan perusahaan. Rasio solvabilitas yang digunakan pada penelitian ini adalah Debt to Equity (DER) dan Debt to Assets (DAR). DER mengukur komposisi hutang dalam modal yang dimiliki perusahaan. Jika nilai DER tinggi artinya modal perusahaan didominasi oleh dana dari kreditur, bukan dari keuangan internal perusahaan. Sedangkan DAR mengukur sejauh mana utang digunakan untuk memperoleh aset perusahaan. Semakin tinggi nilai DAR, maka semakin banyak aset yang dibiayai oleh utang. Nilai DAR dan DER yang tinggi akan meningkatkan risiko perusahaan di masa mendatang, karena jika keadaan ekonomi memburuk atau kinerja perusahaan menurun maka tingkat risiko gagal bayar perusahaan pun semakin tinggi. 


\section{Nilai Perusahaan}

Salvatore (2005) mendefinisikan perusahaan sebagai suatu organisasi yang mengombinasikan berbagai sumber daya dengan tujuan memproduksi barang dan/atau jasa untuk dijual. Berdasarkan theory of firm tujuan utama sebuah perusahaan adalah memaksimumkan kekayaan atau nilai perusahaan (Value of Firm). Nilai perusahaan sendiri didefinisikan sebagai persepsi investor terhadap tingkat keberhasilan perusahaan yang berkaitan dengan harga sahamnya (Sujoko dan Soebiantoro 2007). Sedangkan menurut Husnan dkk (2004) nilai perusahaan adalah harga yang bersedia dikeluarkan oleh calon pembeli jika perusahaan tersebut dijual. Sedangkan Brigham dan Erhardt (2002) berpandangan bahwa nilai perusahaan adalah penentuan perbandingan hasil sebagai kinerja perusahaan yang terdapat di laporan keuangan.

Untuk menghitung nilai perusahaan atau dikenal dengan nama valuasi, menurut Damodaran (2002) dapat dilakukan setidaknya melalui 3 pendekatan yaitu: Relative Valuation, Discounted Cash Flow dan Contingent Claim Valuation. Pendekatan yang digunakan dalam penelitian ini adalah pendekatan relative valuation yang mengestimasi nilai suatu aktiva dibandingkan dengan beberapa aktiva yang berhubungan kepada variabel lain seperti pendapatan, cash flow, book value, dan penjualan.

Perbandingan yang digunakan dalam penelitian-penelitian sebelumnya adalah Price Earning Ratio (PER) dan Price to Book Value (PBV). Price to Book Value (PBV) adalah hasil perhitungan dari harga saham dibagi oleh nilai bukunya (Brigham dan Gapenski 2006). Dalam penelitian yang dilakukan oleh Soliha dan Taswan (2002) dinyatakan bahwa perusahaan yang memiliki PBV tinggi akan meningkatkan kepercayaan pasar terhadap prospek perusahaan yang diindikasikan sebagai kemakmuran bagi pemegang saham. Rasio PBV menunjukkan apakah harga saham suatu perusahaan dijual dalam keadaan overvalue (lebih mahal) atau undervalue (lebih murah) dibandingkan dengan nilai bukunya (Fakhrudin dan Hadianto 2001). Menurut Kasmawati (2016), nilai Tobin's $Q$ juga dapat digunakan untuk menilai sebuah perusahaan. Nilai Tobin's Q dianggap baik jika nilai lebih dari satu (Tobin's $Q>1$ ). Jika perusahaan memiliki nilai Tobin's Q lebih dari satu artinya perusahaan memiliki nilai perusahan (firm value) lebih besar dibandingkan jumlah asetnya. Dengan mengukur Tobin Ratio, investor akan mendapatkan gambaran keadaan fundamental perusahaan dan pandangan pasar terhadap perusahaan. Nilai Tobin's Q yang tinggi juga dapat mengindikasikan manajemen perusahaan berhasil mengelola aset perusahaan.

\section{Perumusan Hipotesis}

\section{Pengaruh Intellectual Capital terhadap Kinerja Keuangan}

Jika perusahaan mampu mengelola sumber daya intelektual (human capital, structural capital, intellectual capital) dengan effisien maka hal tersebut akan berdampak pada meningkatnya kinerja perusahaan (Sunarsih dan Mendra, 2012) . Hasil serupa diperoleh penelitian Chen et al (2005) yang berhasil membuktikan pengaruh intellectual capital terhadap firm value dan financial performance pada perusahaan publik di Taiwan. Selain itu, Yulandari dan Gunawan (2019) juga melakukan penelitian terhadap perusahaan manufaktur di Bursa Efek Indonesia pada 2012 - 2016 yang membuktikan bahwa IC berpengaruh terhadap ROE namun tidak ada pengaruh IC terhadap ROA.

\section{$\mathrm{H}_{1}$ : Intellectual Capital berpengaruh terhadap Kinerja Keuangan}




\section{Pengaruh intellectual capital terhadap nilai perusahaan}

Berdasarkan Teori Stakeholder, seluruh aktivitas manajemen bertujuan menciptakan nilai atau value creation. Kepemilikian dan pemanfaatan Intellectual Capital mampu meningkatkan keunggulan bersaing dan menciptakan nilai tambah terhadap perusahaan. Komponen-komponen intellectual yaitu Human Capital, Structural Capital dan Capital Employed akan membuat perusahaan sustain melalui proses operasi bisnis yang kreatif dan inovatif. Penelitian Chen et al. (2005) menunjukan Intellectual Capital memiliki pengaruh yang siginifikan terhadap nilai perusahaan.

\section{$\mathrm{H}_{2}$ : Intellectual Capital berpengaruh terhadap Nilai Perusahaan}

\section{Pengaruh kinerja keuangan terhadap nilai perusahaan}

Putra dan Juniarni (2017) menyatakan bahwa kinerja keuangan perusahaan berpengaruh positif terhadap nilai perusahaan. Artinya, perusahaan yang memiliki kinerja yang baik dalam membukukan laba akan mendapatkan penilaian positif dari investor. Jika perusahaan memiliki keuntungan yang tinggi maka akan menarik minat para investor untuk menanamkan dananya di perusahaan tersebut. Dengan banyaknya investor yang berminat terhadap suatu perusahaan maka otomatis nilai perusahaan tersebut akan semakin tinggi. Pernyataan ini didukung oleh penelitian yang dilakukan Brimantyo dkk. (2019) yang menyimpulkan adanya pengaruh positif dan signifikan antara kinerja keuangan dan nilai perusahaan. Dari pemaparan tersebut maka hipotesis ketiga penelitian ini adalah :

\section{$\mathrm{H}_{3}$ : Kinerja keuangan berpengaruh terhadap nilai perusahaan}

\section{Metode Penelitian}

\section{Jenis Penelitian dan Gambaran Populasi Penelitian}

Penelitian ini merupakan penelitian kuantitatif yang bertujuan mengetahui hubungan korelasional antara dua variabel atau lebih. Menurut Sugiyono (2009) populasi adalah wilayah generalisasi yang terdiri atas subyek dengan kualitas dan karakterisitik tertentu. Populasi ditetapkan oleh peneliti untuk dipelajari, ditelaah dan kemudian ditarik kesimpulan. Populasi yang digunakan peneliti adalah perusahaan sektor keuangan yang terdaftar di Bursa Efek Indonesia (BEI). Penelitian ini menggunakan periode waktu penelitian 3 tahun yaitu dari tahun $2017-2019$.

\section{Teknik Pengambilan Sampel}

Sampel pada penelitian ini dipilih dengan menggunakan purposive sampling yang berdasarkan pada kriteria-kriteria tertentu karena tidak semua Perusahaan Jasa Keuangan yang terdaftar di Bursa Efek Indonesia digunakan dalam penelitian ini. Adapun kriteria pengambilan sampel dalam penelitian ini adalah (1) Perusahaan telah terdaftar pada sektor keuangan di Bursa Efek Indonesia selama periode 2017-2019. (2) Perusahaan menerbitkan laporan keuangan dan menyediakan data yang dibutuhkan peneliti selama periode 2017-2019. (3) Perusahaaan memiliki laba positif selama periode 2017-2019. (4) Tidak melakukan perubahan nama atau jenis perusahaan selama periode 2017-2019. 


\section{Jenis dan sumber data.}

Jenis data yang digunakan di penelitian ini adalah data sekunder yaitu laporan keuangan (tahunan) yang didapat dari website Indonesia Stock Exchange atau dari website perusahaan terkait.

\section{Definisi Variabel Operasional}

Penelitian ini memiliki 2 jenis variabel yaitu variabel bebas dan terikat. Variabel bebas dalam penelitian ini adalah Intellectual Capital dengan indikator Value Added Intellectual Coefficient. Terdapat 2 variabel terikat dalam penelitian ini yaitu kinerja keuangan dengan indikator ROA, ROE, DAR, DER dan nilai perusahaan dengan indikator EPS, PER, PBV dan Tobin's Q.

\section{Intellectual Capital}

Intellectual Capital merupakan variabel independent yang diukur dengan menggunakan metode Value Added Intellectual Coefficient (VAIC). VAIC dibentuk oleh 3 unsur yaitu Value Added Capital Employed (VACA), Value Added Human Capital (VAHU), Structural Capital Value Added (STVA). VAIC merupakan hasil penjumlahan dari VACA, VAHU dan STVA.

Menurut Ulum (2009) perhitungan VAIC adalah sebagai berikut.

a. Langkah pertama adalah menghitung nilai Value Added (VA)

$$
\mathrm{VA}=\text { Out }- \text { In }
$$

Keterangan :

Out $\quad$ : Total penghasilan yang didapat perusahaan

In : Total pengeluaran atau beban yang dimiliki perusahaan.

b. Langkah kedua menghitung nilai VACA

Keterangan :

$$
\mathrm{VACA}=\frac{\mathrm{VA}}{\mathrm{CE}}
$$

VACA : Rasio antara VA dan CE

VA : Value Added

CE : Capital Employed (Laba Bersih ditambah total ekuitas)

c. Langkah ketiga menghitung nilai VAHU

Keterangan :

$$
\mathrm{VAHU}=\frac{\mathrm{VA}}{\mathrm{HC}}
$$

VAHU : Rasio antara VA dan HC

VA : Value Added

HC : Human Capital (Total beban perusahaan yang berkaitan dengan karyawan)

d. Langkah keempat menghitung nilai STVA

Keterangan :

$$
\text { STVA }=\frac{S C}{V A}
$$

STVA : Rasio antara SC dan VA

VA : Value Added

SC : Structrual Capital, $\mathrm{SC}=\mathrm{VA}-\mathrm{HC}$ 
e. Langkah kelima menghitung nilai VAIC

$$
\mathrm{VAIC}=\mathrm{VACA}+\mathrm{VAHU}+\mathrm{STVA}
$$

VAIC menunjukan seberapa besar intellectual capital yang dimiliki perusahaan untuk menciptakan nilai perusahaan tersebut.

\section{Kinerja Keuangan}

Kinerja keuangan dalam penelitian ini diukur melalui dua rasio profitabilitas dan dua rasio solvabilitas. Rasio profitabilitas yang digunakan dalam penelitian ini adalah Return on Assets (ROA) dan Return on Equity (ROE). Rasio solvabilitas yang digunakan adalah Debt to Assets (DAR) dan Debt to Equity (DER). Berikut adalah cara memperoleh nilai dari setiap indikator :

Tabel 1. Indikator kinerja keuangan

\begin{tabular}{|c|c|c|}
\hline ROE & $R O E=\frac{\text { Laba Bersih }}{\text { Total Ekuitas }}$ & \multirow{2}{*}{$\begin{array}{l}\text { Yulandari dan } \\
\text { Gunawan } \\
(2019)\end{array}$} \\
\hline ROA & $R O A=\frac{\text { Laba Bersih }}{\text { Total Aset }}$ & \\
\hline DER & $D E R=\frac{\text { Total Liabilitas }}{\text { Total Ekuitas }}$ & \multirow[t]{2}{*}{$\begin{array}{l}\text { Fauziah et al. } \\
\text { (2016) }\end{array}$} \\
\hline DAR & $D A R=\frac{\text { Total Liabilitas }}{\text { Total Aset }}$ & \\
\hline
\end{tabular}

(Referensi : data diolah)

\section{Nilai Perusahaan}

Bagi perusahaan yang telah terdaftar di bursa efek, nilai perusahaan tercemin dari harga saham. Perusahaan yang memiliki kinerja yang baik akan memiliki nilai perusahaan yang baik, karena investor akan bersedia membayar lebih bagi perusahaan yang dinilai memiliki kinerja dan prospek yang baik. Penelitian ini menggunakan 4 indikator untuk menghitung nilai sebuah perusahaan, yaitu Earning per Share (EPS), Price to Earning Ratio (PER), Price to Book Value Ratio (PBV), dan Tobin's $Q$. Berikut adalah cara menghitung setiap indikator nilai perusahaan :

Tabel 2. Indikator Nilai Perusahaan

\begin{tabular}{|l|l|c|l|}
\hline $\begin{array}{l}\text { Nilai } \\
\text { Perusahaan }\end{array}$ & EPS & $E P S=\frac{\text { Laba Bersih }}{\text { Jumlah Saham Beredar }}$ & $\begin{array}{l}\text { Fakhrudin } \\
(2017)\end{array}$ \\
\cline { 2 - 4 } & PBV & $P B V=\frac{\text { Harga Saham }}{\text { Harga Buku }}$ & $\begin{array}{l}\text { Fakhrudin } \\
(2017)\end{array}$ \\
\cline { 2 - 4 } & PER & PER $=\frac{\text { Harga Saham }}{\text { Laba Per Saham }}$ & $\begin{array}{l}\text { Brigham dan } \\
\text { Houston : } \\
2006: 110)\end{array}$ \\
\cline { 2 - 4 } & Tobin Q & $\frac{\text { Total Kapitalisasi Pasar }+ \text { Total Liabilitas }}{\text { Total Aset }}$ & $\begin{array}{l}\text { Kasmawati } \\
(2016)\end{array}$ \\
\hline
\end{tabular}

(Referensi : data diolah) 


\section{Metode pengolahan dan analisis data}

Penelitian ini menggunakan analisis deskriptif dan kuantitatif untuk mengelola data. Sedangkan untuk menguji hubungan antar variable peneliti menggunakan alat analisis SEM dengan pendekatan ragam berbasis SmartPLS. Selain SmartPLS, peneliti menggunakan Microsoft Excel untuk menghitung kinerja keuangan dan nilai perusahaan.

\section{Analisis Deskriptif}

Sugiyono (2009) mendefinisikan analisis deskriptif sebagai cara menganlisis data dengan cara menggambarkan atau mendeskriptifkan dengan cara apapun tanpa mengubah kesimpulan yang dimiliki data semula. Analisis deskriptif dilakukan untuk menjelaskan kinerja keuangan dan nilai perusahaan.

\section{SEM Partial Least Square}

Penelitian ini menggunakan alat analisis Partial Least Square Path Modelling (PLS PM), yang merupakan contoh metode analisis berbasis multivariat. Alat analisis ini digunakan untuk menganalisis suatu peubah yang kompleks dengan kemampuan untuk mengetahui pola hubungan antara suatu konstrak dengan indikatornya. Selain itu metode ini juga memiliki kemampuan untuk mengukur suatu kesalahan secara langsung. Dalam Yamin dan Kurniawan (2011), dijelaskan terdapat serangkaian prosedur yang harus dilakukan oleh peneliti ketika menggunakan alat analisis SEM PLS. Langkah tersebut antara lain :

1. Merancang model struktural (inner model)

Langkah pertama, peneliti melakukan formulasi hubungan dengan masing-masing konstrak yang digunakan. Konstrak tersebut harus diketahui secara jelas untuk memudahkan peneliti dalam mendeskirpsikan konstrak tersebut.

2. Mendefinisikan model pengukuran (outer model)

Peneliti menentukan dan mendeskripsikan hubungan peubah laten dengan indikatornya. Hubungan tersebut dapat bersifat formatif maupun reflektif.

3. Membuat diagram alur

Diagram alur ini berfungsi memudahkan peneliti dalam memperjelas model dan menggambarkan pola hubungan indikator berserta konstraknya.

4. Mengkonversi diagram alur yang sudah dibuat ke dalam bentuk persamaan

5. Mengestimasi model

Terdapat tiga skema pemilihan weighting dalam prosedur estimasi model, di antaranya centroid weighting scheme, factor weighting scheme, dan path weighting scheme.

6. Mengevaluasi model .

Pada tahap ini terdapat proses evaluasi model pengukuran dan struktural.

7. Menjelaskan model yang telah dirancang oleh peneliti menurut hasil model yang ditentukan sebelumnya.

8. Pengujian hipotesis

Dalam SEM PLS pengujian hipotesis menggunakan Metode Resampling Bootstrap. Pengujian hipotesis dapat dilihat dengan melihat hasil T-Test. Suatu pengujian dapat diterima apabila memperoleh nilai $p$-value kurang dari 1.96 dengan alpha yang digunakan sebesar $5 \%$. 


\section{Hasil dan Pembahasan}

Peneliti menggunakan alat analisis Structural Equation Modeling (SEM) yang dihitung menggunakan software SmartPLS versi 3.3.2. Peubah laten pada penelitian ini adalah intellectual capital, kinerja keuangan dan nilai perusahaan yang diukur menggunakan berbagai indikator. Terdapat dua tahap dalam melakukan penilaian model PLS yaitu penilaian model pengukuran dan penilaian model struktural ( Yamin dan Kuniawan 2011).

\section{Evaluasi Model Pengukuran (Outer Model)}

Evaluasi model pengukuran digunakan untuk korelasi antar variabel laten bersama dengan paramater penelitian. Menurut Abdillah dan Jogiyono (2015), dalam tahap ini dilakukan pengujian validitas konstruk dan realibilitas instrument. Ketika melakukan uji validitas konvergen, peneliti perlu memperhatikan nilai loading factor setiap indikator dan nilai Average Variance Extracted (AVE). Menurut Schumarker dan Lomax (2004) nilai loading factor harus melebihi 0.7 agar konstruk dapat dikatakan valid dan ideal, sedangkan nilai minimum Average Variance Extracted (AVE) adalah 0.5. Jika sebuah variabel memiliki nilai AVE dibawah 0.5 artinya varians kesalahan lebih banyak daripada varians indikator sehingga variabel dianggap tidak memadai dan tidak valid (Vinzi dkk. 2010). Outer model dan loading factor dalam penelitian ini dapat dilihat di gambar berikut:

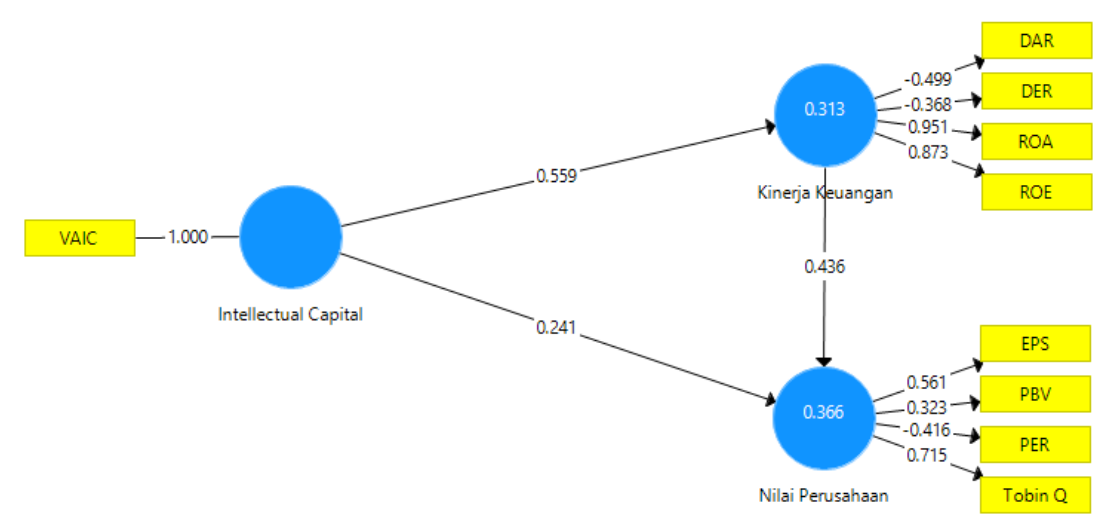

Gambar 1. Outer model dan loading factor (referensi : data diolah)

Dari gambar tersebut terlihat ada beberapa indikator yang memiliki nilai loading factor di bawah 0.7 sehingga harus dilakukan penghapusan (dropping). Indikator kinerja keuangan yang harus dilakukan dropping adalah DAR dan DER dengan nilai loading factor masingmasing -0.499 dan -0.368. Pada variabel nilai perusahaan, indikator yang memenuhi syarat hanya Tobin's Q dengan nilai loading factor 0.715 sedangkan indikator lainnya harus dilakukan dropping, kemudian dilakukan perhitungan kembali untuk mengetahui loading factor dan AVE. Gambar 2 memperlihatkan outer model dan nilai loading factor setelah dilakukan dropping, dan perbandingan nilai AVE sebelum dan setelah dilakukan dropping.

Gambar 2. Outer model setelah dilakukan dropping (referensi: data diolah)

Gambar 2. Outer model setelah dilakukan dropping (referensi: data diolah) 


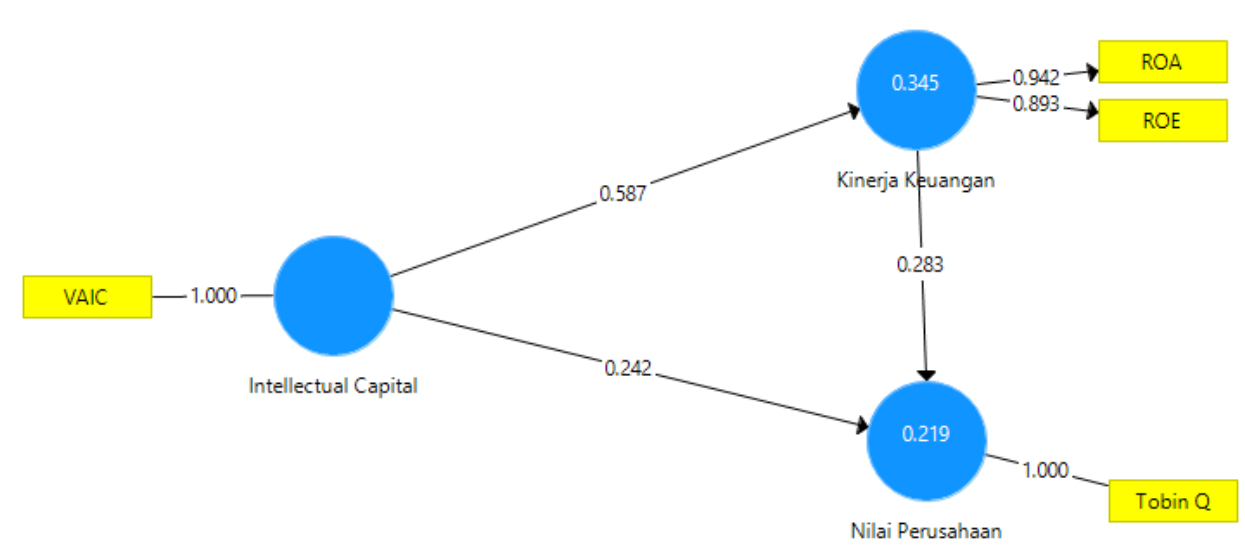

Gambar 2. Outer model setelah dilakukan dropping (referensi: data diolah)

Tabel 3. Average Variable Extracted sebelum dan setelah dilakukan dropping

\begin{tabular}{|l|l|l|}
\hline \multicolumn{1}{|c|}{ Variabel } & AVE sebelum dropping & AVE setelah dropping \\
\hline Kinerja Keuangan & 0.513 & 0.842 \\
\hline Nilai Perusahaan & 0.276 & 1.000 \\
\hline Intellectual Capital & 1.000 & 1.000 \\
\hline
\end{tabular}

(Referensi : data diolah)

Nilai AVE untuk variabel nilai perusahaan sebelum dropping kurang dari 0.5 (tabel 3). Setelah dilakukan dropping, setiap variabel sudah mendapatkan nilai AVE > 0.5 yang berarti varians oleh konstruk lebih besar dari varians yang berasal dari kesalahan pengukuran sehingga dapat disimpulkan model telah baik.

Langkah selanjutnya adalah mengamati nilai cross loading masing-masing indikator untuk menguji validitas diskriminan. Pengujian validitas diskriminan bertujuan untuk menggambarkan seberapa besar sebuah indikator merefleksikan variabel latennya (Hair et al. 2014). Pengujian validitas diskriminan dilakukan dengan menghitung nilai antar variabel dan melihat nilai cross loading yang harus bernilai $>0.7$. Selain itu, nilai loading indikator dengan variabel latennya harus lebih tinggi dibandingkan dengan nilai loading terhadap variabel lainnya. Perhitungan fornell lacker creation dapat dilihat di tabel 4 dan nilai cross loading di tabel 5.

Tabel 4. Nilai Fornell Lacker Creation

\begin{tabular}{|l|c|c|c|}
\hline \multicolumn{1}{|c|}{ Variabel } & Kinerja Keuangan & Nilai Perusahaan & $\begin{array}{c}\text { Intellectual } \\
\text { Capital }\end{array}$ \\
\hline Kinerja Keuangan & 1.000 & & \\
\hline Nilai Perusahaan & 0.587 & 0.918 & 1.000 \\
\hline $\begin{array}{l}\text { Intellectual } \\
\text { Capital }\end{array}$ & 0.408 & 0.425 & \\
\hline
\end{tabular}

(Referensi : data diolah) 
Tabel 5 Nilai Cross Loading

\begin{tabular}{|c|c|c|c|}
\hline Indikator & $\begin{array}{c}\text { Intellectual } \\
\text { Capital }\end{array}$ & Kinerja Keuangan & Nilai Perusahaan \\
\hline ROA & 0.549 & $\mathbf{0 . 9 4 2}$ & 0.518 \\
\hline ROE & 0.529 & $\mathbf{0 . 8 9 3}$ & 0.220 \\
\hline Tobin's Q & 0.408 & 0.425 & $\mathbf{1 . 0 0 0}$ \\
\hline VAIC & $\mathbf{1 . 0 0 0}$ & 0.587 & 0.408 \\
\hline
\end{tabular}

(Referensi : data diolah)

Hasil perhitungan cross loading pada tabel 5 menunjukan intellectual capital, kinerja keuangan, dan nilai perusahaan memiliki nilai loading factor lebih besar untuk setiap laten yang telah dilakukan perhitungan. Hasil cross loading menunjukan bahwa setiap indikator sudah merefleksikan variabel latennya karena memiliki nilai lebih tinggi dibandingkan ukuran konstruk lainnya. Tahapan selanjutnya untuk mengevaluasi outer model adalah melakukan uji realibilitas dengan nilai Cronbach's Alpha dan Compostie Reability. Suatu model dikatakan reliabel jika mencapai nilai cronbach's alpha 0.6 (Hair et al. 2010) dan memiliki nilai composite reability lebih besar dari 0.7 . Setiap variabel sudah reliabel karena sudah memenuhi syarat minimum cronbach's alpha dan composite reability. Nilai Cronbach's Alpha dan Composite Reability dalam penelitian ini dapat dilihat di tabel 6.

Tabel 6 Nilai Cronbach's Alpha dan Compostie Reability

\begin{tabular}{|l|c|c|}
\hline & Cronbach's Alpha & Composite Reability \\
\hline Intellectual Capital & 1.000 & 1.000 \\
\hline Kinerja Keuangan & 0.816 & 0.914 \\
\hline Nilai Perusahaan & 1.000 & 1.000 \\
\hline
\end{tabular}

(Referensi : data diolah)

\section{Evaluasi Model Struktural (Inner Model)}

Evaluasi model struktural dilakukan dengan melihat nilai R Square, yang menjelaskan tingkatan pengaruh variabel eksogen tertentu terhadap variabel laten endogen. Terdapat 3 klasifikasi model dilihat dari nilai R Square-nya yaitu kuat atau substansial (0.67), moderat (0.33), dan lemah (0.19) (Chin 1998). Nilai R Square dalam penelitian dapat dilihat pada tabel 7.

Tabel 7. Nilai $R$ Square

\begin{tabular}{|l|l|}
\hline & R Square \\
\hline Kinerja Keuangan & 0.345 \\
\hline Nilai Perusahaan & 0.219 \\
\hline
\end{tabular}

(Referensi : data diolah)

Nilai R Square variabel kinerja keuangan 0.345 termasuk klasifikasi moderat, yang berarti bahwa variabel intellectual capital dapat menjelaskan variabel kinerja keuangan dengan keragaman sebesar $34.5 \%$ sedangkan $65.5 \%$ dijelaskan oleh variabel lain di luar penelitian ini. Tingkat IC terhadap kinerja keuangan yang berada pada level moderat dapat dikarenakan belum semua perusahaan memperhatikan dan mengelola modal intelektualnya. Hal tersebut dibuktikan dengan banyaknya perusahaan yang tidak membahas modal intelektual dalam 
laporan keuangannya. Nilai R Square variabel nilai perusahaan adalah 0.219 termasuk klasifikasi rendah, yang bermakna indikator intellectual capital dan kinerja keuangan mampu mempengaruhi variabel nilai perusahaan dengan keragaman $21.9 \%$ sedangkan $78.1 \%$ dijelaskan oleh variabel yang tidak digunakan dalam penelitian ini. Faktor nilai R Square untuk nilai perusahaan rendah salah satunya adalah dikarenakan belum banyak investor yang menggunakan modal intelektual sebagai pertimbangan menilai value dari perusahaan.

Langkah berikutnya adalah pengujian hipotesis, yang dapat dilihat dari nilai-nilai pada path coeficient. Arah hubungan antar konstruk ditunjukan oleh nilai original sampel. Hubungan antar kontruk dikatakan positif jika memiliki nilai original sampel positif, begitupun sebaliknya. Selanjutnya dilakukan penilaian tingkat signifikansi yang ditunjukkan oleh nilai $T$ statistics. Pengaruh hubungan antar konstruk dikatakan nyata dan signifikan jika memiiki nilai $T$-statistics $>T$-table. Penelitian ini menggunakan nilai alpha $5 \%$ sehingga nilai $t$-statistics $>$ 1.96 dan nilai $p$-value $<0.05$. nilai path coefficient penelitian ini dapat dilihat di tabel 8 .

Tabel 8. Nilai Path Coefficient

\begin{tabular}{|l|c|c|c|c|c|c|}
\hline & $\begin{array}{c}\text { Original } \\
\text { Sample } \\
(\mathrm{O})\end{array}$ & $\begin{array}{c}\text { Sample } \\
\text { Mean } \\
(\mathrm{M})\end{array}$ & $\begin{array}{c}\text { Standard } \\
\text { Deviation } \\
(\mathrm{STDEV})\end{array}$ & $\begin{array}{c}\text { T Statistics } \\
(|\mathrm{O} / \mathrm{STDEV}|)\end{array}$ & $\begin{array}{c}\mathrm{P} \\
\text { Values }\end{array}$ & Hipotesis \\
\hline $\begin{array}{l}\text { Intellectual Capital -> } \\
\text { Kinerja Keuangan }\end{array}$ & 0.587 & 0.574 & 0.088 & 6.646 & 0.000 & Diterima \\
\hline $\begin{array}{l}\text { Intellectual Capital -> } \\
\text { Nilai Perusahaan }\end{array}$ & 0.242 & 0.241 & 0.099 & 2.430 & 0.015 & Diterima \\
\hline $\begin{array}{l}\text { Kinerja Keuangan -> Nilai } \\
\text { Perusahaan }\end{array}$ & 0.283 & 0.260 & 0.143 & 1.982 & 0.048 & Diterima \\
\hline
\end{tabular}

(Referensi : data diolah)

Dengan data yang didapat dari tabel 8 maka uji hipotesis pada penelitian ini sebagai berikut :

\section{Pengaruh intellectual capital terhadap kinerja keuangan}

Nilai original sample pengujian pengaruh IC terhadap kinerja keuangan adalah 0.587 dan nilai $t$-statistic sebesar 6.646. Hal ini menandakan bahwa IC berpengaruh positif dan nyata terhadap kinerja keuangan, maka hipotesis pertama penelitian ini diterima. Hasil penelitian ini sesuai dengan Faza dan Hidayah (2014) yang menyatakan IC yang diukur menggunakan VAIC berpengaruh positif terhadap ROA dan ROE. Sebelumnya, Tan et al., (2007) meneliti IC di bursa saham Singapura, juga membuktikan intellectual capital memiliki pengaruh positif terhadap kinerja perusahaan kini dan masa mendatang. Hal ini berarti jika nilai intellectual capital perusahaan meningkat maka profitabilitas perusahaan akan turut meningkat.

Kinerja keuangan dalam penelitian ini diukur melalui indikator ROA dan ROE. Artinya, pengelolaan IC yang baik akan meningkatkan kemampuan perusahaan untuk menciptakan laba dari aset yang dimiliki maupun dari dana yang diinvestasikan pemegang saham. Hak ini sesuai dengan resource based theory bahwa IC yang termasuk sumber daya perusahaan akan mampu meningkatkan kemampuan kompetitif perusahaan sehingga kinerja perusahaan menjadi baik dan efektif, termasuk mencetak laba. 


\section{Pengaruh intellectual capital terhadap nilai perusahaan}

Hasil penelitian menunjukan pengaruh positif dan signifikan antara intellectual capital dan nilai perusahaan, yang dibuktikan nilai original sample untuk pengujian pengaruh IC terhadap nilai perusahaan adalah 0.242 dengan nilai $T$-statistic 2.430 . Salah satu faktor yang menyebabkan hasil pengujian pengaruh antara IC dan nilai perusahaan adalah penggunaan Tobin's Q sebagai indikator untuk mengukur nilai perusahaan. Tobin's $Q$ merupakan salah satu rasio yang digunakan untuk melihat value perusahaan. Tobin's $Q$ adalah rasio yang dapat mewakili aset tak berwujud perusahaan, sehingga sesuai dengan konsep intellectual capital yang merupakan salah satu bentuk aset tak berwujud.

Perusahaan yang mampu mengelola dan meningkatkan intellectual capital berarti melakukan peningkatan dalam bidang sumber daya manusia, memperbaiki hubungan dengan stakeholders dan meningkatkan sistem perusahaan dengan baik. Peningkatan unsur intellectual capital akan menciptakan nilai tambah yang diapresiasi pasar, sehingga investor dapat mempertimbangkan nilai VAIC dalam memilih perusahaan. Konsep ini sejalan dengan Resource Based Theory bahwa perusahaan harus mampu mengelola aset tak berwujud agar memiliki kinerja yang efektif dan effisien sehingga tercipta nilai tambah bagi investor dan meningkatkan persepsi yang baik tentang perusahaan. Hasil penelitian ini sependapat dengan Fakhrudin (2017) yang menyimpulkan hubungan positif antara intellectual capital dan nilai perusahaan. Juwita dan Angela (2016) yang meneliti Intellectual Capital pada perusahaan Index Kompas 100 juga menyimpulkan bahwa intellectual capital berpengaruh positif dan signifikan terhadap nilai perusahaan.

\section{Pengaruh kinerja keuangan terhadap nilai perusahaan}

Hipotesis terakhir penelitian ini, pengaruh kinerja keuangan dan nilai perusahaan, juga menunjukan pengaruh positif dan signifikan. Hal tersebut ditunjukkan oleh nilai original sampel untuk uji hipotesis ketiga adalah 0.283 dengan nilai T-statistic 1.982 . Hasil tersebut membuktikan bahwa kinerja keuangan yang diproyeksikan dengan nilai ROA dan ROE berpengaruh positif terhadap nilai perusahaan yang memiliki indikator Tobin's $Q$. Peningkatan kinerja keuangan akan meningkatkan persepsi perusahaan di kalangan investor sehingga akan meningkatkan value perusahaan. Kinerja keuangan dalam penelitian ini adalah ROA dan ROE, yang berarti investor lebih menghargai perusahaan yang mampu mencetak laba dengan baik dari sumber daya yang dimilikinya. Hasil penelitian ini sependapat dengan Putra dan Juniarni (2017) yang juga meneliti pengaruh kinerja keuangan dengan indikator ROA dan ROE terhadap nilai perusahaan yang diproyeksikan oleh nilai Tobin's $Q$.

\section{Kesimpulan}

Dari pemaparan hasil dan pembahasan dapat disimpulkan bahwa semua hipotesis pada penelitian ini diterima. Intellectual capital memiliki pengaruh positif dan signifikan terhadap kinerja keuangan dan nilai perusahaan. Dengan mengelola intellectual capital perusahaan akan mampu meningkatkan kinerja perusahaan menjadi efektif dan efisien, salah satunya adalah kinerja perusahaan dalam mencetak laba. Investor dapat menjadikan intellectual capital 
sebagai pertimbangan memilih perusahaan dalam investasi karena perusahaan dengan nilai Value Added Intellectual Coefficient yang baik akan memiliki kinerja keuangan dan nilai perusahaan yang baik. Perusahaan juga harus mampu mengelola intellectual capital yang mereka miliki agar dapat meningkatkan kinerja perusahaan dan persepsi positif investor.

\section{Daftar Pustaka}

Abdillah W, Jogiyanto. (2015) Partial Least Square (PLS) : Alternatif Structural Equation Modeling (SEM) Dalam Penelitian Bisnis. Yogyakarta, ID: CV Andi Offset.

Bontis, N., Keow, W.C.C. dan Richardson, S. (2000). Intellectual capital and business performance in Malaysian industries. Journal of Intellectual Capital, 1(1), 85-100. https://doi.org/10.1108/14691930010324188

Brigham E.F., dan Ehrhardt M.C. (2002) Financial Management, Theory and Practice $\left(10^{\text {th }}\right.$ Edition). New York : Thomson Learning, Inc.

Brigham, Eugene dan Gapenski, Louis C. (2006). Financial Management : Theory and Practice. Brimantyo, dkk. (2019) Peningkatan Kinerja Keuangan Perusahaan Melalui Struktur Modal Untuk Meningkatkan Nilai Perusahaan. Jurnal Bisnis dan Manajemen, 6(1), 6-14. https://doi.org/10.26905/jbm.v6i1.3030

Chen, M.C., S.J. Cheng, Y. Hwang. (2005). An Empirical Investigation of The Relationship between Intellectual Capital and Firms, Market Value and Financial Performance". Journal of Intellectual Capital, 6(1), 159-176. https://doi.org/10.1108/14691930510592771

CNBC (2020) Bos BCA Ungkap Ancaman Digital Nasabah. Diakses dari https://www.cnbcindonesia.com/tech/20200929110555-37-190192/bos-bca-ungkapancaman-bank-ditinggal-nasabah pada 5 Oktober 2020.

Damodaran, Aswath. (2002). Investment Valuation Tools and Techniques for Determining the Value of Any Asset. New Jersey : John Wiley \& Sons, Inc.

Detik (2017) Ada 3,98 Juta Perusahaan Baru di RI dalam 10 Tahun Terakhir. Diakses dari https://finance.detik.com/berita-ekonomi-bisnis/d-3485474/ada-398-juta-perusahaanbaru-di-ri-dalam-10-tahun-terakhir pada 5 September 2020.

Edvinsson, L. (1997) "Developing Intellectual Capital at Skandia. Long Range Planning" : 366-373. https://doi.org/10.1016/S0024-6301(97)90248-X

Fahmi, Irham. (2012). Analisis Laporan Keuangan. Bandung : Alfabeta.

Fakhruddin, M. 2017. Pengaruh Intellectual Capital dan Kebijakan Dividen Terhadap Nilai Perusahaan. Jurnal Ilmu dan Riset Akuntansi, 6(5), 1756-1772.

Fakhruddin, M dan Hadianto. (2001). Perangkat dan Model Analisis Investasi di Pasar Modal. Jakarta: PT. Elekmedia Komputindo Kelompok Gramedia.

Firer, S. dan Williams, M. (2003). Intellectual capital and traditional measures of corporate performance. Journal of Intellectual Capital, 4(3), 348-60. https://doi.org/10.1108/14691930310487806

Hendra Wijaya. (2017). Agency Costs and Intellectual Capital in Indonesia Manufacturing Firms. Research Journal of Finance and Accounting, 8(24), 36-39.

Hong. (2007). Intellectual Capital and Financial Returns of Companies. Journal of Intellectual Capital, 76 - 95. https://doi.org/10.1108/14691930710715079

Husnan, Suad \& Pudjiastuti, Enny. (2004). Dasar-Dasar Manajemen Keuangan (2 ${ }^{\text {nd }}$ Edition). Yogyakarta: Unit Penerbit dan Percetakan Akademi Perusahaan YKPN.

Juwita, Angela. (2016). Pengaruh Intellectual Capital Terhadap Nilai Perusahaan pada Perusahaan Indeks Kompas 100 di Bursa Efek Indonesia. Jurnal Akuntansi, 8(1), 1-15. 
Kasmawati. (2016). Tobin's q as A Proxy for Corporate Governance Variables and Explanatory Variables in Manufacturing Companies in Jakarta Stock Exchange. International Journal of Recent Scientific Science, 7(6), 11552 - 11558.

Kasmir. (2010). Pengantar Manajemen Keuangan. Jakarta: Kencana Prenada Media Grup.

Lee et al. (2002). Knowledge Intensive Services Activities (KISAs) in Korea's Innovation System. Science and Technology Policy Institute.

Okezone (2020) Astaga! Ada 103 Bank Bankrut Sejak 2006 Hingga 2020. Diakses dari https://economy.okezone.com/read/2020/08/04/320/2256881/astaga-ada-103-bankbangkrut-sejak-2006-hingga-2020 pada 11 September 2020.

Pulic, A. (1998). Measuring the Performance of Intellectual Potential in Knowledge Economy. Paper Presented at the 2nd McMaster World Congress on Measuring and Managing Intellectual Capital by the Austrian Team for Intellectual Potential. Hamilton

Putra dan Juniari. (2017). Analisis Rasio Keuangan terhadap Nilai Perusahan di Bursa Efek Indonesia. Jurnal Riset Akuntansi, 7(2), 143 - 150.

Salvatore, Dominick. (2005). Ekonomi Manajerial dalam Perekonomian Global. Jakarta : Salemba Empat.

Schumacker, R.E., Lomaz, R.G. (2004). A Beginner's Guide to Structural Equation Modeling (2nd Edition). London, GB: Lawrence Erlbaum Assciates, Inc.

Soliha, E., dan Taswan. (2002). Pengaruh Kebijakan Hutang Terhadap Nilai Perusahaan Serta Beberapa Faktor Yang Mempengaruhinya. Jurnal Bisnis dan Ekonomi, 9(2) : 149 163.

Sucipto. (2003). Penilaian Kinerja Keuangan. Didigitalisasi oleh USU digital library.

Sugiyono. (2009). Metode Penelitian Pendidikan Pendekatan Kuantitatif, Kualitatif, dan R\&D. Bandung : Alfabeta.

Sujoko dan Soebiantoro. (2007). Pengaruh Struktur Kepemilikan Saham, Leverage, Faktor Intern dan Faktor Ekstern Terhadap Nilai Perusahaan (Studi empirik pada perusahaan manufaktur dan non manufaktur di Busra Efek Jakarta). Jurnal Manajemen dan Kewirausahaan, 9(1), 41-48.

Sunarsih, N.M dan Ni Putu Yuria Mendra. (2012). Pengaruh Modal Intelektual Terhadap Nilai Perusahaan Dengan Kinerja Keuangan Sebagai Variabel Intervening Pada Perusahaan Yang Terdaftar Di Bursa Efek Indonesia. Makalah Disampaikan dalam Simposium Nasional Akuntansi XV. Banjarmasin: 20-23 September.

Susanto, A.B. (2007) Resource-Based Versus Market-Based. Eksekutif No.333 : 24-25.

Ulum. (2009). Intellectual Capital Performance Sektor Perbankan di Indonesia. Jurnal Akuntansi dan Keuangan, 77 - 84.

Vinzi, V.E., Chin, W.W., Henseler, J., Wang, H. (2010). Handbook of Partial Least Square. London, GB: Springer Heidelberg Dordrecht.

Windrum, dan Tomlinson. (1999). Knowledge-intensive services and international competitiveness: a four country comparison. Technology Analysis and Strategic Management, 11(3), 391 - 408. https://doi.org/10.1080/095373299107429

Yamin S, Kurniawan H. (2011). Generasi Baru Mengolah Data Penelitian dengan Partial Least Square Path Modeling: Aplikasi dengan Software XLSTAT, SmartPLS, dan Visual PLS. Jakarta, ID: Salemba Infotek.

Yulandari dan Gunawan. (2019). Pengaruh Intellectual Capital Terhadap Nilai Pasar dan Kinerja Keuangan Perusahaan Yang Terdaftar Pada Bursa Efek Indonesia. Journal of Applied Managerial Accounting, 3(1), 36-50. https://doi.org/10.30871/jama.v3i1.938 